\title{
Effect of production level and source of fat supplement on performance, nutrient digestibility and blood parameters of heat-stressed Holstein
}

\section{cows}

\author{
Behzad Akhlaghi', Gholam Reza Ghorbani ${ }^{1 *}$, Masoud Alikhani', Shahryar Kargar², Ali Sadeghi-Sefidmazgi', \\ Hassan Rafiee-Yarandi ${ }^{*}$ and Pedram Rezamand ${ }^{3}$
}

${ }^{1}$ Department of Animal Sciences, College of Agriculture, Isfahan University of Technology, Isfahan 4156-83111, Iran

${ }^{2}$ Department of Animal Sciences, College of Agriculture, Shiraz University, Shiraz 71441-65186, Iran

${ }^{3}$ Department of Animal and Veterinary Science, University of Idaho, Moscow Idaho 83844-2330, USA

\section{Abstract}

The interactive effect of dietary fat supplementation and milk yield level on dairy cows performance under heat stress has not been thoroughly investigated. The purpose of this study was to evaluate the effect of production level, the source of fat supplements and their interaction on dairy cows performance under heat stress. In this study, 64 Holstein multiparous cows were divided into 2 groups and received one of two rations having either calcium salts of fatty acids (Ca-FA) or high-palmitic acid (PA) supplements ( $2.8 \%$ of DM; dry matter). After completing the experiment and based on maturity-equivalent milk, cows were divided into two groups of high-yielding $(14,633 \mathrm{~kg})$ and medium-yielding $(11,616 \mathrm{~kg})$. Average temperature humidity index (THI) was 71 during the trial period. Apparent digestibility of dry matter $(p=0.04)$, organic matter $(p=0.05)$, and neutral detergent fiber (NDF; $p=0.04$ ) for cows fed Ca-FA were greater than cows fed PA. The milk fat content in high-producing cows was $0.3 \%$ greater than medium-producing cows $(p=0.03)$. The milk protein content in cows fed Ca-FA was greater than cows fed PA $(p<0.01)$. High-producing cows had greater serum cholesterol $(p=0.02)$ than medium-producing cows. The cows fed PA tended to have a greater BUN than cows fed Ca-FA $(p=0.06)$. Alanine aminotransferase and aspartate aminotransferase tended to be increased by PA, which indicates that cows in PA treatment may have experienced more adverse effect on the liver function than cows on Ca-FA. Therefore, under heat stress and in $90 \mathrm{~d}$ trial, milk production level does not affect the cows' response to PA or Ca-FA. Although cows fed Ca-FA received lower energy than those fed PA, they compensated for this shortage likely with increasing the digestibility and produced a similar amount of milk. Keywords: Calcium salts of fatty acid, Heat stress, Palmitic acid, Production level

Received: Jun 22, 2019 Revised: Sept 11,2019 Accepted: Sept 26, 2019

"Corresponding author: Gholam Reza Ghorbani, Department of Animal Sciences, College of Agriculture, Isfahan University of Technology, Isfahan 4156-83111, Iran.

Tel: +98-913-116-0490, E-mail: ghorbani@cc.iut.ac.ir

Hassan Rafiee-Yarandi, Department of Animal Sciences, College of Agriculture, Isfahan University of Technology, Isfahan 4156-83111, Iran.

Tel: +98-919-484-4881, E-mail: harafiee@yahoo.com

This is an Open Access article distributed under the terms of the Creative Commons Attribution Non-Commercial License (http://creativecommons.org/licenses/by$\mathrm{nc} / 4.0 /$ ) which permits unrestricted non-commercial use, distribution, and reproduction in any medium, provided the original work is properly cited.

Copyright (c) 2019 Korean Society of Animal Science and Technology. 


\section{Background}

The response to fat supplement in dairy cows can vary significantly [1]. For example, 1.5 to 2 percent saturated fat of dietary dry matter (DM) had different effects on cow performance compared with a ration with other fat supplements, including increase in milk yield [2], or no difference in production [3]. Part of the variation in response to fat supplements can be explained by the lactation stage, level of production, environmental conditions, the type of fat and their interactions [4]. Environmental conditions including heat stress (THI > 68) can affect the cow performance. Cows subjected to the heat stress experience the metabolic changes, which reduce their feed intake and ultimately their milk yield [5]. To compensate for energy shortages under heat stress, neutral ruminal fats are commonly used. Use of neutral ruminal fats such as calcium salts of fatty acids (Ca-FA) or high palmitic acid (PA) may increase the performance of dairy cows under heat stress [6].

Moreover, cows with different levels of production have different physiology and metabolism [7], which can affect their response to dietary fat supplementation. For example, feeding saturated fat in comparison with unsaturated fat increased the production of milk protein in high-producing cows compared with low-producing cows [8]. Furthermore, the use of Ca-FA reduced milk fat in high-yielding cows, but did not affect the low-yielding cows [7,9].

Another important factor causing different responses is the source of fat (Ca-FA and PA). Feeding high-yielding cows with $\mathrm{PA}$, compared with $\mathrm{Ca}-\mathrm{FA}$, under no heat stress resulted in an increase of $1.7 \mathrm{~kg} /$ day in milk and $40 \mathrm{~g} /$ day in milk fat yield [4]. This increased production was partly related to the fact that cows fed PA tended to have a higher feed intake [4]. When the same experiment was repeated in summer taking into account the production level of the cows, it did not reveal any interaction between the production level and fat source on the milk production and ingredients except that high-yielding cows fed $\mathrm{Ca}$-FA had a lower milk fat compared with high-yielding cows fed PA [7].

Moreover, most studies on the effect of fat on dairy cows, in short-term of 21-day, have been conducted using Latin Square design $[4,9,10]$. Some report that Latin Square designs (with 21day periods) are not suitable for estimating the effect of fats on the performance of dairy cows, and can have carry-over effects [1].

To our knowledge, no study has evaluated various sources of fat (Ca-FA vs $\mathrm{PA})$ in the ration of the dairy cows under heat stress and based on the production level in a 90-d trial. Therefore, the aim of this study was to evaluate the interaction between production level and source of fat supplement and their effect on milk production and ingredients, digestibility of nutrients and biochemical parameters of blood in Holstein dairy cows under heat stress. We hypothesized that under heat stress condition different source of fat would affect cow performance with different level of productivity.

\section{Materials and Methods}

\section{Environmental measurements and calculation of tem-} perature-humidity index

The study was conducted from July to October 2013. To calculate the temperature-humidity index (THI), ambient temperature $\left(\mathrm{T}_{\mathrm{db}}\right.$, $\left.{ }^{\circ} \mathrm{C}\right)$ and relative humidity $(\mathrm{RH}, \%)$ were recorded using a temperature and humidity data-logger (ST-172; Fotronic Co., Melrose, MA) every 15 min: THI $=\left(1.8 \times \mathrm{T}_{\mathrm{db}}+32\right)-[(0.55-0.0055 \times$ $\left.\mathrm{RH}) \times\left(1.8 \times \mathrm{T}_{\mathrm{db}}-26.8\right)\right]$ [11]. All animal procedures were conducted under protocols approved by the Animal Care and Use Committee of the Iranian Council of Animal Care [12].

\section{Cows management and treatments}

The study was conducted at a commercial dairy farm (Fude farm; Isfahan, Iran). Cows were kept in two free-stall barns, and housing and feeding management was the same for all cows. Sixty four Holstein multiparous cows were selected and divided into 2 groups ( $n=32$ /group) over a total period of 90 days and randomly assigned to $\mathrm{Ca}-\mathrm{FA}$ or high-palmitic acid (PA) diets. After completing the experiment and based on maturity-equivalent milk, cows were divided into two groups of high-yielding $(59.6 \pm 21$ DIM, parity $=2.6 \pm 0.7$, milk production $=52.6 \pm 7.1 \mathrm{~kg} / \mathrm{d}$; mean $\pm \mathrm{SE}$ ) and medium-yielding (57.2 $\pm 22 \mathrm{DIM}$, parity $=2.6 \pm 0.7$, milk production $=46.0 \pm 6.5 \mathrm{~kg} / \mathrm{d}$; mean $\pm \mathrm{SE}$ ).

Cows were fed either a diet with $2.8 \% \mathrm{Ca}-\mathrm{FA}$ or a diet with $2.8 \%$ PA on a DM basis. Energizer RP10 (IFFCO, Kuala Lumpur, Malaysia) was the PA used, which contained $99 \%$ total fatty acids (FA) as 85\% C16:0 and 2\% C18:0. Energizer Gold (IFFCO, Kuala Lumpur, Malaysia) was the $\mathrm{Ca}-\mathrm{FA}$ used, which contained $13 \%$ ash, $2.5 \%-5 \%$ moisture, $8.5 \%-10 \%$ calcium, and $87.5 \%$ total FA as 0.2\% C12:0; $1.2 \% \mathrm{C} 14: 0 ; 47.6 \% \mathrm{C} 16: 0 ; 5 \% \mathrm{C} 18: 0 ; 38 \% \mathrm{C} 18: 1$; and $8 \% \mathrm{C} 18: 2$. Diets were formulated to be similar in crude protein (CP) and neutral detergent fiber (NDF), and dietary net energy of lactation $\left(\mathrm{NE}_{\mathrm{L}}\right)$ values were 1.77 and $1.74 \mathrm{Mcal} / \mathrm{kg}$, for the $\mathrm{PA}$ and $\mathrm{Ca}-\mathrm{FA}$, respectively. Ingredients and chemical composition of the different diets are shown in Table 1.

\section{Sampling, measurements, and analyses}

Cows were fed a total mixed ration (TMR) three times daily at approximately 0500,1230 , and $1700 \mathrm{~h}$, in amounts that resulted in 5\%-10\% orts. Cows had free access to water. The TMR for each free-stall barn were prepared separately and the fat supplements were mixed properly and precisely. Samples of TMR were collected weekly and frozen at $-20^{\circ} \mathrm{C}$ until further analysis. The DM 
Table 1. Feed ingredients and chemical composition of experimental diets on a dry matter basis

\begin{tabular}{|c|c|c|}
\hline \multirow{2}{*}{ Item } & \multicolumn{2}{|c|}{ Experimental diets } \\
\hline & PA & Ca-FA \\
\hline \multicolumn{3}{|l|}{ Ingredient (g/kg DM) } \\
\hline Corn silage & 265.9 & 265.9 \\
\hline Alfalfa hay & 114.7 & 114.7 \\
\hline Ground barley & 180.4 & 180.4 \\
\hline Ground corn & 152.5 & 152.5 \\
\hline Ground wheat & 23.0 & 23.0 \\
\hline Whole cottonseed & 47.1 & 47.1 \\
\hline Roasted soybean & 14.1 & 14.1 \\
\hline Soybean meal & 92.2 & 92.2 \\
\hline SigmaPlus ${ }^{1)}$ & 10.6 & 10.6 \\
\hline Canola meal & 23.5 & 23.5 \\
\hline Meat meal & 9.30 & 9.30 \\
\hline Fish meal & 8.80 & 8.80 \\
\hline Smart-amine & 0.50 & 0.50 \\
\hline C16:0 enriched palm fat ${ }^{2}$ & 28.0 & - \\
\hline Ca-salts of palm fat ${ }^{3)}$ & - & 28.0 \\
\hline Vitamin-mineral mixture ${ }^{4)}$ & 2.60 & 2.60 \\
\hline Sodium-bicarbonate & 11.0 & 11.0 \\
\hline Calcium carbonate & 7.80 & 7.80 \\
\hline Di-calcium phosphate & 2.50 & 2.50 \\
\hline Salt & 4.60 & 4.60 \\
\hline \multicolumn{3}{|l|}{ Chemical composition } \\
\hline $\mathrm{DM}(\mathrm{g} / \mathrm{kg})$ & 442 & 452 \\
\hline $\mathrm{NE}_{\mathrm{L}}^{5)}(\mathrm{Mcal} / \mathrm{kg} \mathrm{DM})$ & 1.77 & 1.74 \\
\hline CP (g/kg DM) & 163 & 166 \\
\hline NDF (g/kg DM) & 333.2 & 341.6 \\
\hline ADF (g/kg DM) & 224.4 & 225.7 \\
\hline $\mathrm{NFC}^{6)}(\mathrm{g} / \mathrm{kg} \mathrm{DM})$ & 428 & 435 \\
\hline Fat (g/kg DM) & 66 & 61 \\
\hline Ash (g/kg DM) & 80 & 89 \\
\hline
\end{tabular}

${ }^{1)}$ By-pass soybean meal: Mehr Bisotune, Isfahan, Iran.

${ }^{2)}$ Energizer RP10, IFFCO, Malaysia. Composition: crude fat 99\% (C16:0, 85\%; C18:0, $2 \%)$.

${ }^{3)}$ Energizer Gold, IFFCO, Malaysia. Composition: ash 13\%, moisture 2.5\%-5\%, calcium 8.5\%-10\%, crude fat 87.5\% (C12:0, 0.2\%; C14:0, 1.2\%; C16:0, 47.6\%; C18:0, $5 \%$; C18:1, 38\%; C18:2, 8\%).

${ }^{4)}$ Composition: $10 \mathrm{~g} / \mathrm{kg}$ of $\mathrm{Mn}, 16 \mathrm{~g} / \mathrm{kg}$ of $\mathrm{Zn}, 4 \mathrm{~g} / \mathrm{kg}$ of $\mathrm{Cu}, 0.15 \mathrm{~g} / \mathrm{kg}$ of I, $0.12 \mathrm{~g} / \mathrm{kg}$ of Co, $0.8 \mathrm{~g} / \mathrm{kg}$ of Fe, 1,300,000 IU/kg of vitamin A, 360,000 IU/kg of vitamin D, and $12,000 \mathrm{IU} / \mathrm{kg}$ of vitamin $\mathrm{E}, 0.08 \mathrm{~g} / \mathrm{kg}$ of Se.

${ }^{5)}$ Calculated from NRC [37].

${ }^{6)}$ Nonfibrous carbohydrates [NFC = OM - (NDF + CP + EE)].

$\mathrm{PA}$, high-palmitic acid; Ca-FA, calcium salts of fatty acids; $\mathrm{DM}$, dry matter; $\mathrm{NE}_{\mathrm{L}}$, net energy of lactation; $C P$, crude protein; NDF, neutral detergent fiber; ADF, acid detergent fiber; NFC, non-fiber carbohydrates; OM, organic matter; EE, ether extract.

content of the diets was determined by drying in a forced-air oven at $60^{\circ} \mathrm{C}$ for $48 \mathrm{~h}$. Weekly dried diet samples were ground (Wiley mill, Arthur H. Thomas, Swedesboro, NJ 08085 U.S.A) using a 1 -mm screen and analyzed for composition. The ground samples in three replicate were analyzed for NDF with sodium sulfite and heat stable $\alpha$-amylase (100 $\mu \mathrm{L} /$ sample) and acid detergent fiber (ADF) according to Van Soest et al. [13]. Contents of DM, ash, $\mathrm{CP}$, and ether extract were analyzed according to AOAC International [14]. Fecal grab samples were obtained from each cow once every two weeks after morning and afternoon feeding. Fecal grab samples frozen at $-20^{\circ} \mathrm{C}$ until further analysis. Samples were dried in a forced-air oven at $60^{\circ} \mathrm{C}$ for $72 \mathrm{~h}$, ground to pass through a 1-mm screen, and analyzed for $\mathrm{DM}$, ash, $\mathrm{ADF}, \mathrm{NDF}, \mathrm{CP}$, and ether extract, as described for feeds and orts. Apparent total-tract digestibilities of nutrients were obtained using the acid-insoluble ash internal marker method [15].

Cows were milked four times daily at 0600, 1200, 1600 and 2400 h. Milk yield was recorded once every two weeks from individual cows. Milk samples from individual cows were collected from four consecutive milking and composited by each milking on the first day of trial and every two weeks thereafter. Milk samples were analyzed for fat, crude protein and total solid (TS) by Milkoscan (134 BN Foss Electric, Hillerød, Denmark). The milk urea nitrogen (MUN) content was determined by enzymatic assay [16]. Yields of milk components were calculated by multiplying the concentration of the component by the yield of milk at each milking time on days during which the sample was taken.

Body condition (BCS) [17] was scored by two experienced scorers at the beginning and end of each experimental period. Backfat thickness (BFT) was measured according to Schröder and Staufenbiel [18] at an imaginary line between the hooks and pins at the sacral examination site once weekly by ultrasound (SonoVet 600 V; BCF Technology Ltd., West Lothian, UK). Cow health was monitored daily by dairy personnel and weekly by the research staff.

\section{Ruminal fermentation, blood metabolites and reproduc-} tive data

Blood samples from the coccygeal vessel were collected in evacuated tubes with anticoagulant (EDTA) at approximately $4 \mathrm{~h}$ post-feeding on the first day of trial and monthly thereafter. Samples were centrifuged for $20 \mathrm{~min}$ at $3,000 \times \mathrm{g}$ at $4{ }^{\circ} \mathrm{C}$ for plasma separation, and each sample was divided into 3 aliquots and frozen at $-20^{\circ} \mathrm{C}$ until analysis. Concentrations of plasma glucose, total cholesterol, total triacylglycerol, low-density lipoprotein cholesterol, total protein, albumin, blood urea N (BUN; Pars Azmoon Co., Tehran, Iran), aspartate transaminase (AST), and alanine transaminase (ALT, Pars Azmoon Co., Tehran, Iran) were determined automatically by using standard test kits on an ALCYON 300i 


\section{JAST}

automatic analyzer (Abbott Laboratories Ltd., Chicago, IL). The analyzer was calibrated with the control sera $\mathrm{N}$ and $\mathrm{P}$ (TrueLab $\mathrm{N}^{\circledR}$ and TrueLab $\mathrm{P}^{\circledR}$, respectively; Pars Azmoon Co., Tehran, Iran) and a calibrator solution (TrueCal $\mathrm{U}^{\circledR}$, Pars Azmoon Co., Tehran, Iran) to ensure acceptable assay performance. Globulin concentrations was obtained by deducting albumin from total protein.

Additionally, $5 \mathrm{~mL}$ of blood samples was collected into sodium-heparinized Vacutainers (Becton Dickinson Co., Rutherford, NJ, USA), which were immediately placed on ice and transported to the laboratory. Hematological analysis was performed on all blood samples using an Automated Sysmex hematology analyzer (model K-1000; Black Scientific Inc., Bellport, NY).

On the last day of experiment, ruminal fluid was sampled from six cows in each treatments, approximately $3-4 \mathrm{~h}$ after the morning feeding, using a stomach tube connected to a vacuum pump. The first $50 \mathrm{~mL}$ of the aspirated rumen fluid was discarded to minimize saliva contamination. The $\mathrm{pH}$ was measured immediately, using a portable digital $\mathrm{pH}$ meter (HI 8314 membrane $\mathrm{pH}$ meter, Hanna Instruments, Villafranca, Italy). Then, ruminal liquor samples were strained through two layers of cheesecloth. A sub-sample of strained ruminal fluid was analyzed for $\mathrm{NH}_{3}$ by the colorimetric phenol-hypochlorite method [19]. Another sub-sample (15 mL) of strained ruminal fluid was diluted with $3 \mathrm{~mL}$ of $25 \%$ metaphosphoric acid for VFA analysis using gas chromatography $(0.25 \times$ 0.32, $0.3 \mu \mathrm{m}$ i.d. fused silica capillary, model no. CP-9002 Vulcanusweg 259 a.m., Chrompack, Delft, The Netherlands).

Reproductive data (service per conception, conception rate, proportion pregnant, open days, and daughter pregnancy rate) were obtained. The voluntary waiting period of the herd was $60 \mathrm{~d}$, and cows were inseminated based on a voluntary waiting period. All cows were observed for signs of estrus for a 30-min period three times daily and were inseminated within $12 \mathrm{~h}$ of detected estrus. Pregnancy diagnosis was performed by ultrasonography (Easi-Scan version 3, BCF Technology Ltd, Livingston, UK) at $30 \mathrm{~d}$ after AI. Cows diagnosed pregnant at $\mathrm{d} 30$, were re-examined by rectal palpation at $60 \pm 3 \mathrm{~d}$ after $\mathrm{AI}$ to confirm pregnancy.

\section{Statistical analyses}

Statistical analyses were performed by ANOVA using the MIXED procedure of SAS (version 9.1.22, SAS Institute Inc., 2002) using the following model: $Y_{i j k l}=\mu+P L_{i}+F S_{j}+(P L \times F S)_{i j}+T_{k}+(P L \times T)_{i k}$ $+(F S \times T)_{j k}+(P L \times F S \times T)_{i j k}+\beta(X i-\bar{X})+e_{i j k l}$ where $Y_{i j k l}$ is the dependent variable; $\mu$ is the overall mean; $P L_{i}$ is the effects of production level (high and medium), $F S_{j}$ is the effects of supplement fat sources (PA and $\mathrm{Ca}-\mathrm{FA}),(P L \times F S)_{i j}$ is the effect of the interaction between production level and supplement fat sources; $T_{k}$ is the effect of time, $(P L \times T)_{i k}$ is the effect of the interaction between production level and time; $(F S \times T)_{j k}$ is the interaction between supplement fat sources and time; $(P L \times F S \times T)_{i j k}$ is the tripartite effect of production level, supplement fat sources and time; $\beta(X i$ $-\bar{X})$ is the covariate variable and $e_{i j k l}$ is the overall error term. The time effect and time $\times$ production level, time $\times$ fat source, and time $\times$ fat source $\times$ production level interactions were not significant for any variable, and they were pooled with the error term in the final model. In addition, the cow effect was used as a random effect in the model. Reproductive data were analyzed using GLIMMIX procedure of SAS fitting a binary distribution response.

Milk production and composition, and the blood biochemical parameters on the first day of trial were included as covariate in the model when analyzing performance and blood biochemical parameters data. Normality of distribution and homogeneity of variance for residuals were tested using PROC UNIVARIATE [20]. The lowest Bayesian information criteria was used for choosing the best-fit covariance structure for each repeated measures. The best-fit covariance structure was first-order autoregressive covariance structure $[\mathrm{AR}(1)]$. All differences were tested using the Tukey-Kramer procedure, and significance was declared at $p \leq 0.05$ while a trend was noted if $0.05<p \leq 0.10$.

\section{Results}

\section{Diets composition}

The only difference between two diets was the type of fat supplements. In both rations, fat supplement was used at $2.8 \% \mathrm{DM}$ and because the PA has more fat, fat content of the ration reached $6.6 \%$ whereas fat content of the ration with $\mathrm{Ca}-\mathrm{FA}$ reached $6.1 \%$. This difference in fat content gave rise to a difference in the energy level of two diets. The $\mathrm{NE}_{\mathrm{L}}$ content of ration with $\mathrm{PA}$ and with $\mathrm{Ca}-\mathrm{FA}$ was 1.77 and $1.74 \mathrm{Mcal} / \mathrm{kg}$ of DM, respectively.

\section{Environmental condition}

Diurnal and temporal pattern of $\mathrm{RH}$, temperature and temperature-humidity index (THI) are shown in Fig. 1A and 1B, respectively. On average, cows experience the THI of higher than 68, between 70 and 72, and higher that 72 in 17, 6, and 10 hours per day, respectively. The average THI for entire trial period was 71 .

\section{Dry matter intake and digestibility}

There was no difference in DMI between treatments with different fat supplements, 23.5 and $24.5 \mathrm{~kg} /$ day for $\mathrm{PA}$ and $\mathrm{Ca}-\mathrm{FA}$, respectively $(\mathrm{SEM}=0.45, p=0.56)$. The production level had no dateable effect on total tract digestibility and there were no significant interactions (Table 2). Digestibility of DM ( $p=0.04)$, organic matter ( $p$ $=0.05)$, and NDF $(p=0.04)$ in cows fed Ca-FA was greater than cows fed PA. 


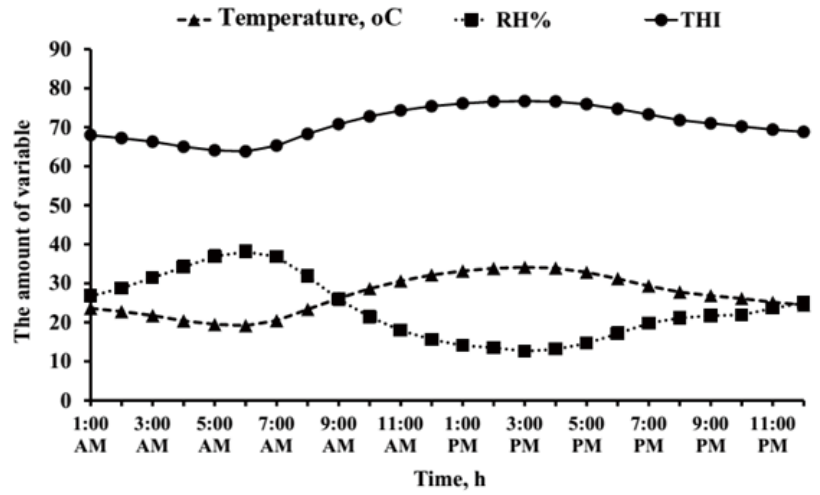

A

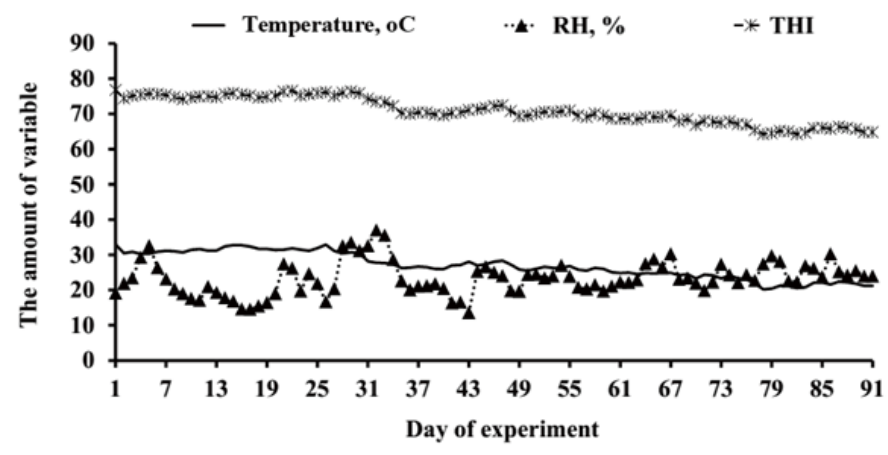

B

Fig. 1. Diurnal pattern of relative humidity (RH), temperature and temperature-humidity index (THI) of the animal facility $A$ and temporal pattern of THI during the experimental period $B$.

\section{Milk yield and composition}

As expected, high-yielding cows had a greater average milk yield ( 47.4 vs $44.3 \mathrm{~kg} / \mathrm{d}, p=0.05$ ), fat corrected milk (FCM) yield (41.5 vs $32.6 \mathrm{~kg} / \mathrm{d}, p<0.01$ ), and milk components (Table 3 ) compared with those for medium-yielding cows. The milk fat content was lower in medium-yielding cows than high-yielding cows $(2.6 \%$ vs $2.9 \%, p=0.03)$. The type of fat supplement showed no detectable effect on milk production and milk fat. The milk protein content was greater in cows on $\mathrm{Ca}-\mathrm{FA}$ than cows on $\mathrm{PA}(3.0 \%$ vs $2.9 \%, p$ $<0.01)$. There was no interaction detected between the production level and type of fat supplement on lactation performance. Similarly, production level and type of fat had no effect on the average BCS and back fat thickness.

\section{Blood biochemical parameters and whole blood cell} count

High-yielding cows had a higher level of plasma cholesterol $(p=$ $0.02)$ than medium-yielding cows (Table 4). Cows on PA tended to have a greater BUN $(p=0.6)$, and there was also a weak tenden- cy $(p=0.11)$ to increase liver enzymes of AST and ALT compared with cows fed $\mathrm{Ca}$-FA. The number of white blood cells, monocytes and lymphocytes numerically were higher in cows fed PA than those fed Ca-FA (Table 5).

\section{Rumen parameters and reproductive performance}

The effect of production level and type of fat supplements and their interaction on rumen parameters was not significant (Table 6). Interaction between production level and type of fat was significant on the day of the first insemination (Fig. 2). The effect of production level and type of fat supplements on other reproductive measures were not significant (Table 7).

\section{Discussion}

Meteorology data in this experiment showed that cows experienced a mild to moderate heat stress during the trial period [11].

In previous studies, the use of fat supplements had a mixed effect on the DMI. Some research, similar to our results, reported no

Table 2. Least squares means of nutrient digestibility for high $(n=32)$ and medium $(n=32)$ producing dairy cows receiving either calcium salts of fatty acids (Ca-FA) or high-palmitic acid (PA) during a heat stress period

\begin{tabular}{|c|c|c|c|c|c|c|c|c|}
\hline \multirow{2}{*}{ Item } & \multicolumn{2}{|c|}{ High production } & \multicolumn{2}{|c|}{ Medium production } & \multirow{2}{*}{ SEM } & \multicolumn{3}{|c|}{$p$-value } \\
\hline & PA & Ca-FA & PA & Ca-FA & & PL & FS & $\mathrm{PL} \times \mathrm{FS}$ \\
\hline DM & 69.83 & 72.77 & 68.61 & 72.07 & 0.44 & 0.56 & 0.04 & 0.84 \\
\hline OM & 72.32 & 73.67 & 71.72 & 73.33 & 1.31 & 0.47 & 0.05 & 0.85 \\
\hline $\mathrm{CP}$ & 66.60 & 70.14 & 67.50 & 68.07 & 1.44 & 0.77 & 0.37 & 0.50 \\
\hline NDF & 54.87 & 60.63 & 53.28 & 60.48 & 1.88 & 0.75 & 0.04 & 0.80 \\
\hline $\mathrm{ADF}$ & 48.21 & 50.64 & 44.73 & 50.79 & 1.70 & 0.48 & 0.12 & 0.46 \\
\hline Fat & 75.15 & 77.58 & 72.15 & 75.41 & 2.19 & 0.45 & 0.39 & 0.92 \\
\hline
\end{tabular}

$\mathrm{PL}$, production level; FS, fat source; PL $\times \mathrm{FS}$, interaction between production level and fat source; $\mathrm{DM}$, dry matter; OM, organic matter; CP, crude protein; NDF, neutral detergent fiber; ADF, acid detergent fiber. 
Table 3. Least squares means of milk yield and composition for high $(n=32)$ and medium $(n=32)$ producing dairy cows receiving either calcium salts of fatty acids (Ca-FA) or high-palmitic acid (PA) during a heat stress period

\begin{tabular}{|c|c|c|c|c|c|c|c|c|}
\hline \multirow{2}{*}{ Item } & \multicolumn{2}{|c|}{ High production } & \multicolumn{2}{|c|}{ Medium production } & \multirow{2}{*}{ SEM } & \multicolumn{3}{|c|}{$p$-value } \\
\hline & PA & Ca-FA & PA & Ca-FA & & PL & FS & $\mathrm{PL} \times \mathrm{FS}$ \\
\hline Milk (kg/d) & 47.48 & 47.36 & 44.87 & 43.78 & 0.95 & 0.05 & 0.69 & 0.72 \\
\hline $3.5 \% \mathrm{FCM}^{1}(\mathrm{~kg} / \mathrm{d})$ & 41.66 & 40.17 & 35.71 & 34.65 & 1.16 & $<0.01$ & 0.44 & 0.89 \\
\hline Fat (\%) & 2.90 & 2.89 & 2.75 & 2.45 & 0.08 & 0.03 & 0.17 & 0.21 \\
\hline Fat $(\mathrm{kg} / \mathrm{d})$ & 1.46 & 1.38 & 1.21 & 1.11 & 0.05 & $<0.01$ & 0.28 & 0.89 \\
\hline Protein (\%) & 2.85 & 3.01 & 2.90 & 3.06 & 0.03 & 0.32 & 0.01 & 0.87 \\
\hline Protein $(\mathrm{kg} / \mathrm{d})$ & 1.40 & 1.44 & 1.26 & 1.35 & 0.02 & 0.02 & 0.11 & 0.57 \\
\hline MUN (mg/dL) & 12.20 & 10.08 & 13.63 & 12.07 & 1.25 & 0.43 & 0.95 & 0.49 \\
\hline BCS & 2.60 & 2.54 & 2.59 & 2.66 & 0.04 & 0.41 & 0.93 & 0.29 \\
\hline Back fat thickness (mm) & 24.84 & 25.53 & 25.22 & 24.33 & 0.94 & 0.76 & 0.94 & 0.57 \\
\hline
\end{tabular}

${ }^{1)} 3.5 \% \mathrm{FCM}=(0.432 \times$ milk yield $)+(16.23 \times$ fat yield $)$.

$\mathrm{PL}$, production level; FS, fat source; PL $\times$ FS, interaction between production level and fat source; FCM, fat corrected milk; MUN, milk urea nitrogen; $B C S$, body condition score.

difference in the intake of saturated fat and Ca-FA in low (18-25 $\mathrm{kg} / \mathrm{d})[21,22]$ or high $(42 \mathrm{~kg} / \mathrm{d})[23,24]$ yielding cows. In contrast to our results however, Harvatine and Allen [8] and Rico et al. [4] noted that $\mathrm{Ca}-\mathrm{FA}$ decreased the DMI compared with PA. It has been generally stated that fat supplements reduces the DMI and the greater the content of unsaturated fat the higher decrease in DMI [1]. Patra [25] reported that addition of fats in diets showed a quadratic response on DMI, although the relationship was very low. In that study, the quadratic broken line analysis indicated that DMI increased a little from $14.3 \mathrm{~kg} / \mathrm{d}$ to $14.9 \mathrm{~kg} / \mathrm{d}$ at fat concen- trations of $4.2 \%$ of diet DM, and thereafter DMI decreased. In high producing cows, such as our research, the level of fat generally is higher than $4.2 \%$ and it caused the reduction in DMI, as Rabiee et al. [1] reported.

In line with our finding (Table 2), Piantoni et al. [2] also noted that the level of milk production did not affect digestibility of nutrients. In previous studies, contrary to our results, it was reported that saturated fat supplement did not affect the digestibility of $\mathrm{DM}$ and NDF at the levels of $3.0 \%$ to $3.5 \%$ of DM in both low $(18-25 \mathrm{~kg} / \mathrm{d})[21,22,26]$ and high $(42 \mathrm{~kg} / \mathrm{d})[24,27]$ yielding

Table 4. Least squares means of blood biochemical parameters for high $(n=32)$ and medium $(n=32)$ producing dairy cows receiving either calcium salts of fatty acids (Ca-FA) or high-palmitic acid (PA) during a heat stress period

\begin{tabular}{|c|c|c|c|c|c|c|c|c|}
\hline \multirow{2}{*}{ Item } & \multicolumn{2}{|c|}{ High production } & \multicolumn{2}{|c|}{ Medium production } & \multirow{2}{*}{ SEM } & \multicolumn{3}{|c|}{ p-value } \\
\hline & PA & Ca-FA & PA & Ca-FA & & PL & FS & $\mathrm{PL} \times \mathrm{FS}$ \\
\hline \multicolumn{9}{|l|}{ Metabolites (mg/dL) } \\
\hline Glucose & 57.20 & 59.70 & 57.17 & 56.21 & 1.99 & 0.53 & 0.82 & 0.52 \\
\hline Triglyceride & 16.16 & 11.67 & 12.40 & 11.64 & 1.09 & 0.08 & 0.05 & 0.08 \\
\hline Cholesterol & 288.06 & 281.85 & 188.78 & 252.22 & 17.50 & 0.02 & 0.35 & 0.16 \\
\hline LDL & 68.65 & 63.35 & 40.86 & 56.83 & 7.71 & 0.12 & 0.67 & 0.30 \\
\hline VLDL & $2.84^{\mathrm{a}}$ & $2.43^{b}$ & $2.39^{b}$ & $2.50^{\mathrm{ab}}$ & 0.08 & 0.10 & 0.28 & 0.03 \\
\hline BUN & 16.59 & 14.06 & 17.64 & 15.58 & 0.64 & 0.18 & 0.06 & 0.79 \\
\hline \multicolumn{9}{|l|}{ Enzymes (U/L) } \\
\hline Aspartate transferase & 123.31 & 101.49 & 128.76 & 81.86 & 11.96 & 0.67 & 0.11 & 0.44 \\
\hline Alanine transferase & 25.57 & 24.51 & 26.82 & 21.61 & 1.06 & 0.57 & 0.11 & 0.17 \\
\hline \multicolumn{9}{|l|}{ Plasma proteins $(\mathrm{g} / \mathrm{dL})$} \\
\hline Total protein & 8.73 & 8.76 & 8.42 & 8.79 & 0.14 & 0.48 & 0.42 & 0.38 \\
\hline Albumin & 4.06 & 4.25 & 4.23 & 4.33 & 0.07 & 0.22 & 0.24 & 0.63 \\
\hline Globulin & 4.66 & 4.50 & 4.19 & 4.45 & 0.18 & 0.33 & 0.87 & 0.41 \\
\hline
\end{tabular}

PL, production level; FS, fat source; PL × FS, interaction between production level and fat source; LDL, low density lipoprotein; VLDL, very low density lipoprotein; BUN, blood urea nitrogen.

${ }^{a, b}$ Different superscripts within a row indicate significant differences at $p<0.05$. 
Table 5. Least squares means of complete blood count for high $(n=32)$ and medium $(n=32)$ producing dairy cows receiving either calcium salts of fatty acids (Ca-FA) or high-palmitic acid (PA) during a heat stress period

\begin{tabular}{|c|c|c|c|c|c|c|c|c|}
\hline \multirow{2}{*}{ Item } & \multicolumn{2}{|c|}{ High production } & \multicolumn{2}{|c|}{ Medium production } & \multirow{2}{*}{ SEM } & \multicolumn{3}{|c|}{$p$-value } \\
\hline & PA & Ca-FA & PA & Ca-FA & & PL & FS & PL $\times F S$ \\
\hline \multicolumn{9}{|l|}{ Complete blood count $\left(10^{9} / \mathrm{L}\right)$} \\
\hline Platelets & 265.53 & 278.89 & 229.07 & 258.37 & 14.88 & 0.17 & 0.35 & 0.70 \\
\hline Red blood cells & 5.93 & 6.20 & 6.06 & 6.11 & 0.10 & 0.88 & 0.31 & 0.45 \\
\hline White blood cells (WBC) & 11.97 & 10.46 & 12.04 & 8.04 & 2.77 & 0.76 & 0.52 & 0.76 \\
\hline \multicolumn{9}{|l|}{ WBC differential $\left(10^{9} / \mathrm{L}\right)$} \\
\hline Lymphocyte & 5.90 & 3.84 & 5.80 & 3.59 & 1.66 & 0.94 & 0.40 & 0.97 \\
\hline Monocyte & 0.40 & 0.29 & 0.26 & 0.08 & 0.17 & 0.48 & 0.59 & 0.90 \\
\hline Eosinophil & 0.34 & 0.30 & 0.37 & 0.13 & 0.15 & 0.74 & 0.54 & 0.66 \\
\hline Basophil & 0.05 & 0.04 & 0.06 & 0.01 & 0.03 & 0.82 & 0.62 & 0.67 \\
\hline Neutrophil/granulocyte & 5.26 & 5.97 & 5.39 & 4.21 & 0.93 & 0.54 & 0.86 & 0.49 \\
\hline \multicolumn{9}{|l|}{ WBC differential (\%) } \\
\hline Lymphocyte & 43.35 & 37.22 & 42.66 & 45.73 & 3.14 & 0.38 & 0.75 & 0.32 \\
\hline Monocyte & 2.31 & 2.37 & 1.71 & 1.28 & 0.48 & 0.25 & 0.75 & 0.78 \\
\hline Eosinophil & 2.20 & 2.29 & 2.38 & 1.79 & 0.40 & 0.78 & 0.68 & 0.56 \\
\hline Basophil & 0.24 & 0.23 & 0.28 & 0.29 & 0.13 & 0.79 & 0.99 & 0.93 \\
\hline Neutrophil/granulocyte & 51.80 & 57.97 & 52.23 & 50.98 & 3.90 & 0.55 & 0.68 & 0.52 \\
\hline
\end{tabular}

$\mathrm{PL}$, production level; FS, fat source; $\mathrm{PL} \times \mathrm{FS}$, interaction between production level and fat source.

cows compared with Ca-FA. In line with our findings, Freitas et al. [10] reported that digestibility of FA and DM was higher for cows fed Ca-FA compared with that for cows fed supplement fatfree ration. Harvateine and Allen [8] noted that unsaturated fat reduced the rumination time compared with that for saturated fat; this reduction was related to decreased ruminal movements and increased feed retention time in the digestive tract, which also increases the digestibility of nutrients, especially NDF [2]. In general, whereas fat supplements increase the dietary energy but their effects depend on the digestibility of added FA and how they affect digestibility of other nutrients [28]. In the present study, although cows fed PA received more fat than cows fed $\mathrm{Ca}-\mathrm{FA}$, because of increased digestibility of nutrients in $\mathrm{Ca}-\mathrm{FA}$ treatments, amount of energy received was not different from that for PA treatment and therefore milk production was not affected.

In the present study, high-yielding cows had a greater level of plasma cholesterol (Table 4), which suggests that high-yielding cows may have derived more triglyceride from the liver for the milk fat production, leading to increased milk fat content for these cows (Table 3). Qu et al. [29] also indicated that during the heat stress, high yielding cows derived more triglycerides from the liver than low-yielding cows, helping to maintain milk production or

Table 6. Least squares means of rumen parameters for high $(n=32)$ and medium $(n=32)$ producing dairy cows receiving either calcium salts of fatty acids (Ca-FA) or high-palmitic acid (PA) during a heat stress period

\begin{tabular}{|c|c|c|c|c|c|c|c|c|}
\hline \multirow{2}{*}{ Item } & \multicolumn{2}{|c|}{ High production } & \multicolumn{2}{|c|}{ Medium production } & \multirow{2}{*}{ SEM } & \multicolumn{3}{|c|}{$p$-value } \\
\hline & PA & Ca-FA & PA & Ca-FA & & PL & FS & $\mathrm{PL} \times \mathrm{FS}$ \\
\hline $\mathrm{pH}$ & 6.25 & 6.45 & 6.31 & 6.14 & 0.20 & 0.67 & 0.97 & 0.54 \\
\hline $\mathrm{NH}_{3}(\mathrm{mg} / \mathrm{dL})$ & 8.05 & 9.17 & 10.26 & 11.70 & 1.35 & 0.23 & 0.55 & 0.93 \\
\hline Total VFA (mM) & 89.78 & 83.53 & 89.60 & 93.79 & 9.92 & 0.71 & 0.94 & 0.71 \\
\hline Acetate $(\mathrm{mol} / 100 \mathrm{~mol})$ & 50.68 & 47.56 & 49.81 & 53.21 & 4.69 & 0.71 & 0.98 & 0.62 \\
\hline Propionate $(\mathrm{mol} / 100 \mathrm{~mol})$ & 25.10 & 24.73 & 26.80 & 26.78 & 4.39 & 0.76 & 0.97 & 0.97 \\
\hline Butyrate $(\mathrm{mol} / 100 \mathrm{~mol})$ & 11.04 & 8.65 & 9.61 & 10.54 & 0.91 & 0.85 & 0.61 & 0.23 \\
\hline Valerate $(\mathrm{mol} / 100 \mathrm{~mol})$ & 1.38 & 1.14 & 1.38 & 1.50 & 0.22 & 0.58 & 0.86 & 0.58 \\
\hline Iso-butyrate (mol/100 mol) & 1.56 & 1.43 & 1.98 & 1.75 & 0.20 & 0.22 & 0.57 & 0.84 \\
\hline Acetate:Propionate & 2.16 & 2.03 & 1.94 & 2.08 & 0.21 & 0.78 & 0.99 & 0.66 \\
\hline
\end{tabular}

$\mathrm{PL}$, production level; FS, fat source; $\mathrm{PL} \times \mathrm{FS}$, interaction between production level and fat source. 


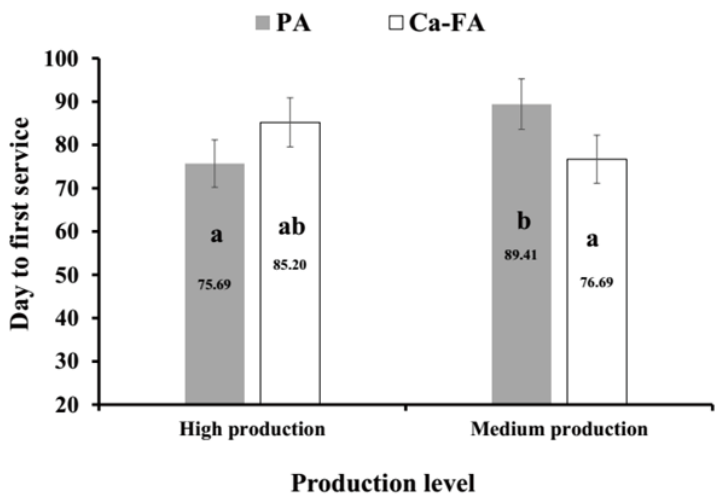

Fig. 2. Day to first service (pooled SEM $=3.8$ ) for high and medium production cows fed calcium salts of fatty acids (Ca-FA) or highpalmitic acid (PA) diets during a heat stress period. There was a production level $\times$ fat source interaction $(p=0.03)$ for day to first service.

milk fat during the heat stress. Similar to our results, it was reported that the milk production level and PA had no interactive effect on milk production and composition [2]. In addition, Rico et al. [7] compared the effect of saturated and Ca-FA in cows with two levels of production (42 and $29 \mathrm{~kg}$ ) and found that there was no difference in milk production level. Milk protein and production was also unaffected by the production level and type of fat supplements [7], however, Ca-FA feeding reduced milk fat in high-yielding cows but not in low-yielding cows compared with saturated fat [7]. Harvatine and Allen [9] also noted that the production level and type of fat supplements did not interactively affect milk production and type of fat did not make any difference in milk production. In a field study, milk production level increased for cows fed saturated fat supplement compared with cows fed fatfree diet with low-yielding cows experiencing larger increase [6]. In another study, saturated and $\mathrm{Ca}-\mathrm{FA}$ showed no effect on milk production and composition [22]. In heat stress, saturated fat and $\mathrm{Ca}-\mathrm{FA}$ had no effect on the milk production and protein but milk fat decreased with $\mathrm{Ca}-\mathrm{FA}$ [30].

In general, Rabiei et al. [1] noted that the use of fat supple- ments in the diet reduced the milk protein content and the greater amount of unsaturated fat, the lower milk protein content. It was shown that increase in milk protein in high-yielding cows was larger than low-yielding cows in response to saturated versus unsaturated fat [8].

Juchem et al. [23] and Weiss et al. [24] reported that Ca-FA reduced milk protein content compared with saturated fat, which is likely related to the reduced DMI, thus reducing the intake of metabolizable protein. Different reasons were provided for the milk protein reduction resulting from use of fat supplements including the diluting effect, such that fat supplements increases the milk production, but milk protein production is not increased too and milk is diluted [8]. Grummer [21] also noted that saturated fat had no effect on the reduction of milk protein content compared with the fat-free diet, but unsaturated fat reduced the milk protein by $13 \%$.

In the current study, the effect of fat supplements on milk protein is not consistent with other reports and milk protein content in cows fed Ca-FA was higher than those fed PA (Table 3). Research indicated that saturated fat increases insulin and insulin resistance in cells $[8,31]$ and consequently cells employ protein and amino acids as sources of energy, which in turn results in the reduction of amino acids transported to the mammary tissue and possibly lower protein production in the mammary tissue [8]. Another possible reason for the effect of unsaturated fat in lowering milk protein is the negative effect of unsaturated fat on rumen microbes and reduced production of microbial protein [8]. In the present study however, because the rumen profile was not affected (Table 6) and NDF digestibility was also higher in Ca-FA and milk fat was not also decreased, it might be concluded that $\mathrm{Ca}-\mathrm{FA}$ had no adverse effect on fermentation in the rumen. On the other hand, $\mathrm{Ca}-\mathrm{FA}$ in the present study increased digestibility of DM and NDF, which probably increases the production of microbial protein and ultimately milk protein.

In contrast to our results, Karcagi et al. [32] reported that when comparing control (no fat) and Ca-FA feeding, cows fed PA had

Table 7. Least squares means of reproductive performance for high $(n=32)$ and medium $(n=32)$ producing dairy cows receiving either calcium salts of fatty acids (Ca-FA) or high-palmitic acid (PA) during a heat stress period

\begin{tabular}{|c|c|c|c|c|c|c|c|c|}
\hline \multirow{2}{*}{ Item } & \multicolumn{2}{|c|}{ High production } & \multicolumn{2}{|c|}{ Medium production } & \multirow{2}{*}{ SEM } & \multicolumn{3}{|c|}{$p$-value } \\
\hline & PA & Ca-FA & PA & Ca-FA & & PL & FS & PL $\times$ FS \\
\hline Daughter pregnancy rate (DPR) & 0.36 & 0.43 & 0.37 & 0.34 & 0.11 & 0.82 & 0.92 & 0.79 \\
\hline Services per conception & 3.17 & 2.55 & 2.62 & 2.88 & 0.54 & 0.88 & 0.76 & 0.43 \\
\hline Open days & 147.55 & 147.41 & 144.66 & 143.61 & 4.66 & 0.50 & 0.89 & 0.92 \\
\hline Conception rate at first $\mathrm{Al}(\%)$ & 35.29 & 30.76 & 23.66 & 30.00 & 0.73 & 0.63 & 0.46 & 0.87 \\
\hline Conception rate at total of $3 \mathrm{AI}(\%)$ & 82.35 & 92.30 & 72.72 & 83.33 & 0.77 & 0.14 & 0.69 & 0.28 \\
\hline Proportion pregnant (\%) & 86.30 & 93.33 & 86.36 & 92.59 & 0.45 & 0.95 & 0.31 & 0.98 \\
\hline
\end{tabular}

$\mathrm{PL}$, production level; FS, fat source; $\mathrm{PL} \times \mathrm{FS}$, interaction between production level and fat source; $\mathrm{Al}$, artificial inseminations. 
lowest triglycerides concentration during the transition period. We did not find any other report for comparison of $\mathrm{PA}$ and $\mathrm{Ca}-\mathrm{FA}$ in blood biochemical parameters. Qu et al. [29] noted that production level had not effect on the cholesterol levels, but VLDL was higher in high-yielding cows than low yielding ones under heat stress.

Plasma cholesterol, triglycerides and lipoproteins may be associated with the energy and fat intake. Given that high-yielding cows generally have greater DMI, their cholesterol levels have also increased (Table 4). Qu et al. [29] noted that high-yielding cows transferred greater amount of triglyceride from liver to the bloodstream than low-yielding cows, which can be then used to produce milk fat or be employed in other tissues. And as a result, the effect of the negative energy balance is decreased and cows can maintain a high level of production. The reason for the increase in BUN in cows consuming PA is not clear, but might be related to (numerical) increase in protein digestibility in cows fed $\mathrm{Ca}-\mathrm{FA}$, which in turn may boost the protein metabolism and reduce the BUN levels.

The number of white blood cells, monocytes and lymphocytes numerically were higher in cows fed PA than those fed Ca-FA (Table 5). The reason why feeding PA could reduce the number of platelets is not known. Increase in the white blood cell population is one of the most important biomarkers for physiological stresses such as heat stress and susceptibility to diseases [5,33]. New research is needed to learn how the number of blood cells and their activity can be affected by the source of fat used in the diet.

The effect of production level and type of fat supplements and their interaction on rumen parameters was not significant (Table 6). Interaction between production level and type of fat was significant on the day of the first insemination and medium production cows fed PA had longest days to first service (Fig. 2). A study reported that $\mathrm{Ca}-\mathrm{FA}$ improved the pregnancy rate in the early stages of gestation period in beef cattle [34,35]. In addition, the beneficial effects of $\mathrm{Ca}-\mathrm{FA}$ in reproduction were independent of its contribution to dietary energy [34]. The beneficial effects of $\mathrm{Ca}-\mathrm{FA}$ include increased progesterone turnover, maintenance and preservation of pregnancy [35].

Generally, cows in current experiment had low reproduction efficiency and across all treatments, the services per conception and conception rate at first $\mathrm{AI}$ averaged $2.8 \%$ and $30 \%$, respectively (Table 7). In agreement with our results, it was noted that summer heat stress is a major cause of low fertility in dairy cattle. Heat stress during the summer disrupts several reproductive processes, resulting in a pronounced depression of conception rate in dairy cows worldwide [36].

\section{Conclusion}

The results of this research indicated that although cows con- suming $\mathrm{Ca}$-FA received less energy, they compensated such an energy shortage likely through improved digestibility. Furthermore, high-yielding cows under heat stress could more efficiently use dietary fat supplements compared with medium-yielding cows so that milk fat content in high-yielding cow was greater than medium-yielding cows. Moreover, under the heat stress, PA could decrease milk protein possibly through increasing the plasma insulin and reducing the body fat release. The number of white blood cells and liver enzymes in cows fed PA was higher, indicating that these cows may have been under more stress compared with cows fed Ca-FA. It may be assumed that PA had a greater effect on the milk and milk fat production while $\mathrm{Ca}-\mathrm{FA}$ had a greater effect on health. In addition, the use of $\mathrm{PA}$ or $\mathrm{Ca}-\mathrm{FA}$ at a level of $3 \%$ in the diet made no major difference in terms of performance. Overall, the production level showed no detectable interaction with PA or $\mathrm{Ca}-\mathrm{FA}$ under heat stress, and high or medium producing cows responded to both $\mathrm{PA}$ and $\mathrm{Ca}-\mathrm{FA}$ in a non-significantly different manner.

\section{Competing interests}

No potential conflict of interest relevant to this article was reported.

\section{Funding sources}

The current work is part of project funded by the Isfahan University of Technology.

\section{Acknowledgements}

The authors thank Fude farm Isfahan, Iran, for their support of this research.

\section{Availability of data and material}

Upon reasonable request, the datasets of this study can be available from the corresponding author.

\section{Authors' contributions}

Conceptualization: Ghorbani GR, Alikhani M.

Methodology: Sadeghi-Sefidmazgi A.

Investigation: Akhlaghi B.

Writing - original draft: Rafiee-Yarandi H, Kargar S.

Writing - review \& editing: Akhlaghi B, Ghorbani GR, Alikhani M, Kargar S, Sadeghi-Sefidmazgi A, Rafiee-Yarandi H, Rezamand $\mathrm{P}$.

\section{Ethics approval and consent to participate}

All animal procedures were conducted under protocols approved by the Animal Care and Use Committee of the Iranian Council of Animal Care. 
JAST

\section{ORCID}

Behzad Akhlaghi https://orcid.org/0000-0001-8282-0667

Gholam Reza Ghorbani https://orcid.org/0000-0002-2136-6090

Masoud Alikhani https://orcid.org/0000-0002-8392-7017

Shahryar Kargar https://orcid.org/0000-0003-0418-1868

Ali Sadeghi-Sefidmazgi https://orcid.org/0000-0001-6261-4057

Hassan Rafiee-Yarandi https://orcid.org/0000-0002-4230-2598

Pedram Rezamand https://orcid.org/0000-0002-1014-7140

\section{References}

1. Rabiee A, Breinhild K, Scott W, Golder HM, Block E, Lean IJ. Effect of fat additions to diets of dairy cattle on milk production and components: a meta-analysis and meta-regression. J Dairy Sci. 2012;95:3225-47.

2. Piantoni P, Lock AL, Allen MS. Palmitic acid increased yields of milk and milk fat and nutrient digestibility across production level of lactating cows. J Dairy Sci. 2013;96:7143-54.

3. Lock AL, Preseault CL, Rico JE, DeLand KE, Allen MS. Feeding a C16:0-enriched fat supplement increased the yield of milk fat and improved conversion of feed to milk. J Dairy Sci. 2013;96:6650-9.

4. Rico DE, Ying Y, Harvatine KJ. Comparison of enriched palmitic acid and calcium salts of palm fatty acids distillate fat supplements on milk production and metabolic profiles of high-producing dairy cows.J Dairy Sci. 2014;97:5637-44.

5. Armstrong DV. Heat stress interaction with shade and cooling.J Dairy Sci. 1994;77:2044-50.

6. Warntjes JL, Robinson PH, Galo E, DePeters EJ, Howes D. Effects of feeding supplemental palmitic acid (C16:0) on performance and milk fatty acid profile of lactating dairy cows under summer heat.J Anim Feed Sci. 2008;140:241-57.

7. Rico DE, Ying Y, Harvatine KJ. Effect of a high-palmitic acid fat supplement on milk production and apparent total-tract digestibility in high- and low-milk yield dairy cows. J Dairy Sci. 2014;97:3739-51.

8. Harvatine KJ, Allen MS. The effect of production level on feed intake, milk yield, and endocrine responses to two fatty acid supplements in lactating cows.J Dairy Sci. 2005;88:4018-27.

9. Harvatine KJ, Allen MS. Effects of fatty acid supplements on milk yield and energy balance of lactating dairy cows. J Dairy Sci. 2006;89:1081-91.

10. Freitas Junior JE, Renno FP, Gandra JR, Renno LN, Rego AC, Santos MV, et al. Addition of unsaturated fatty acids improves digestion of mid lactating dairy cows. Arch Zootec. 2014;63:563-73.

11. Dikmen S, Hansen PJ. Is the temperature-humidity index the best indicator of heat stress in lactating dairy cows in a sub- tropical environment? J Dairy Sci. 2009;92:109-16.

12. Iranian Council of Animal Care. Guide to the care and use of experimental animals. Vol. 1. Isfahan (Iran): Isfahan University of Technology; 1995.

13. Van Soest PJ, Robertson JB, Lewis BA. Methods for dietary fiber, neutral detergent fiber, and nonstarch polysaccharides in relation to animal nutrition. J Dairy Sci. 1991;74:3583-97.

14. AOAC. Official methods of analysis. 17th ed. Washington, DC: Association of Official Analytical Chemists; 2002.

15. Van Keulen J, Young BA. Evaluation of acid-insoluble ash as natural marker in ruminant digestibility studies. J Anim Sci. 1977;44:282-7.

16. Wilson RC, Overton TR, Clark JH. Effects of Yucca shidigera extract and soluble protein on performance of cows and concentrations of urea nitrogen in plasma and milk. J Dairy Sci. 1998;81:1022-7.

17. Edmonson AJ, Lean IJ, Weaver LD, Farver T, Webster G. A body condition scoring chart for Holstein dairy cows. J Dairy Sci. 1989;72:68-78.

18. Schroder UJ, Staufenbiel R. Methods to determine body fat reserves in the dairy cow with special regard to ultrasonographic measurement of backfat thickness. J Dairy Sci. 2006;89:1-14.

19. Broderick GA, Kang JH. Automated simultaneous determination of ammonia and total amino acids in ruminal fluid and in vitro media. J Dairy Sci. 1980;63:64-75.

20. SAS Institute. SAS user's guide: Statistics. Version 9.1. Cary (NC): SAS Institute; 2004.

21. Grummer RR. Influence of prilled fat and calcium salt of palm oil fatty acids on ruminal fermentation and nutrient digestibility. J Dairy Sci. 1988;71:117-23.

22. Schauff DJ, Clark JH. Effects of prilled fatty acids and calcium salts of fatty acids on rumen fermentation, nutrient digestibilities, milk production, and milk composition. J Dairy Sci. 1989;72:917-27.

23. Juchem SO, Santos JEP, Cerri RLA, Chebel RC, Galvao $\mathrm{KN}$, Bruno R, et al. Effect of calcium salts of fish and palm oils on lactational performance of Holstein cows. J Anim Sci. 2008;140:18-38.

24. Weiss WP, Pinos-Rodriguez JM, Wyatt DJ. The value of different fat supplements as sources of digestible energy for lactating dairy cows. J Dairy Sci. 2011;94:931-9.

25. Patra AK. The effect of dietary fats on methane emissions, and its other effects on digestibility, rumen fermentation and lactation performance in cattle: a meta-analysis. Livest Sci. 2013;155:244-54.

26. Palmquist DL. Influence of source and amount of dietary fat on digestibility in lactating cows. J Dairy Sci. 1991;74:1354- 
60.

27. Harvatine KJ, Allen MS. Effects of fatty acid supplements on ruminal and total tract nutrient digestion in lactating dairy cows. J Dairy Sci. 2006;89:1092-103.

28. Allen MS, Bradford BJ, Harvatine KJ. The cow as a model to study food intake regulation. Annu Rev Nutr. 2005;25:523-47.

29. Qu M, Wei S, Chen Z, Wang G, Zheng Y, Yan P. Differences of hormones involved in adipose metabolism and lactation between high and low producing Holstein cows during heat stress. Anim Nut. 2015;1:339-43.

30. Moore CE, Kay JK, Collier RJ, Vanbaale MJ, Baumgard LH. Effect of supplemental conjugated linoleic acids on heat-stressed Brown Swiss and Holstein cows. J Dairy Sci. 2005;88:1732-40.

31. Relling AE, Reynolds CK. Feeding rumen-inert fats differing in their degree of saturation decreases intake and increases plasma concentrations of gut peptides in lactating dairy cows.J Dairy Sci. 2007;90:1506-15.

32. Karcagi RG, Gaal T, Ribiczey P, Huszenicza G, Husveth F. Milk production, peripartal liver triglyceride concentration and plasma metabolites of dairy cows fed diets supplemented with calcium soaps or hydrogenated triglycerides of palm oil.J Dairy Res. 2010;77:151-8.

33. Azab ME, Abdel-Maksoud HA. Changes in some hematological and biochemical parameters during prepartum and postpartum periods in female Baladi goats. Small Rumin Res. 1999;34:77-85.

34. Lopes CN, Cooke RF, Reis MM, Peres RF, Vasconcelos JL. Strategic supplementation of calcium salts of polyunsaturated fatty acids to enhance reproductive performance of Bos indicus beef cows. J Anim Sci. 2011;89:3116-24.

35. Lopes CN, Scarpa AB, Cappellozza BI, Cooke RF, Vasconcelos JL. Effects of rumen-protected polyunsaturated fatty acid supplementation on reproductive performance of Bos indicus beef cows. J Anim Sci. 2009;87;3935-43.

36. Wolfenson D, Roth Z. Impact of heat stress on cow reproduction and fertility. Anim Frontiers. 2019;9:32-8.

37. NRC [National Research Council]. Nutrient requirements of dairy cattle. 7th rev. ed. Washington, DC: National Academy Press; 2001. 